\title{
ON SOME MEDUSAE OF THE GENERA PODOCORYNE AND PHIALOPSIS
}

\author{
By F. S. Russell, F.R.S. \\ Naturalist at the Plymouth Laboratory
}

(Text-figs. I-3)

It is generally assumed that there are two species of the genus Podocoryne, in northern waters, in which free swimming medusae are produced, $P$. carnea M. Sars and P. areolata Alder. Of these, the hydroid of P. carnea is known for certain, and that of $P$. areolata is thought to be the hydroid described by Alder under that specific name. Recently, I have found that there are two more species of Podocoryne medusae in British waters, $P$. hartlaubi Neppi $\&$ Stiasny and $P$. minima (Trinci). There are, therefore, two more hydroids to be found and it will be shown that the identity of the hydroid of the so-called medusa $P$. areolata must remain in doubt.

\section{Podocoryne hartlaubi Neppi \& Stiasny}

While on a cruise on the S.S. George Bligh in the mouth of the English Channel in April I938 I obtained a specimen of Podocoryne about whose identity I was in doubt. The medusa had thirty-four marginal tentacles, but its mouth lips were undivided and each had a single terminal nematocyst cluster. The medusa thus agreed with $P$. carnea in the characters of its mouth, but with $P$. areolata as regards the number of marginal tentacles, for no undoubted $P$. carnea have yet been recorded from European waters with more than eight tentacles.

On looking through the collections of the late $\mathrm{Mr} \mathrm{E}$. T. Browne I came across a medusa labelled Cytaeandra n.sp., caught at Valentia on August II I899. I saw at once that this was the same species that I had found, and the specimen was quite perfect, the stomach being torn in my own specimen. In $\mathrm{Mr}$ Browne's medusa (Fig. I $a$ ) it could be seen that each gonad extended for a short distance along the proximal portion of the radial canal. In this respect it resembled exactly the medusa figured by Neppi \& Stiasny (1913) as Podocoryne hartlaubi from the Gulf of Trieste.

$\mathrm{Mr}$ Browne's specimen and mine had forty-four and thirty-four marginal tentacles respectively, of which the four perradial and four interradial were large and approximately of the same size, the remaining tentacles being small and of different sizes (Fig. I $b$ ). Neppi and Stiasny in their description give the number of tentacles as $c a$. I8; in their figure, however, these authors show two to three small tentacles between every two large tentacles, making 
a total of between twenty-four and thirty-two. I think there can be no doubt that the British specimens are $P$. hartlaubi, and it might be expected that

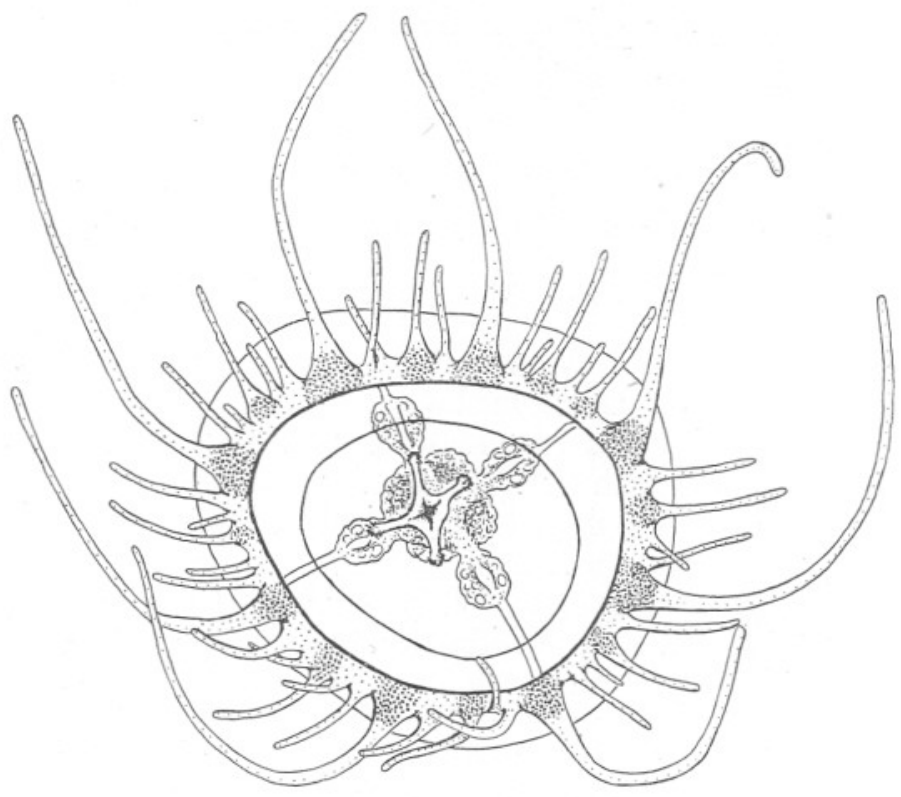

$C$

$a$
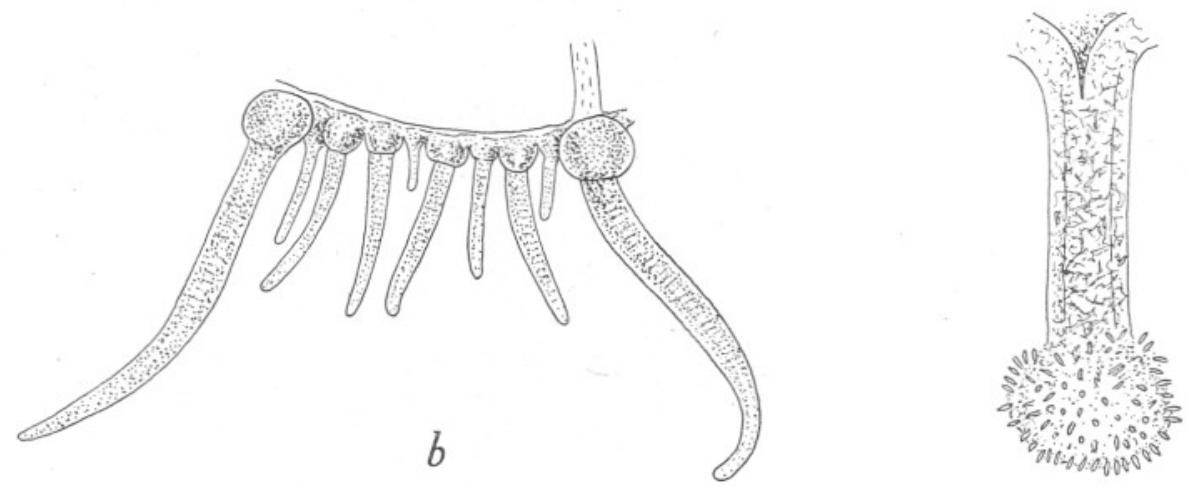

Fig. I. Podocoryne hartlaubi: $a, 2 \mathrm{~mm}$. diameter, Valentia, Aug. II I899; $b$, octant of margin of specimen $3.8 \mathrm{~mm}$. diameter; $c$, gonads on proximal portion of radial canal; $d$, mouth lip.

the medusa should have more tentacles in northern waters than in the Mediterranean.

Mr P. G. Corbin kindly allowed me to look through a ring trawl catch taken in the same position as that in which I caught my original specimen. I found 
two more specimens, with forty-eight and fifty-seven tentacles respectively, and in each a characteristic feature was the large size of eight only of the tentacles. These medusae were obviously the same species as mine, but in one the stomach was badly torn and in the other it was completely missing.

The details of these four specimens were as follows:

\begin{tabular}{|c|c|c|c|}
\hline \multirow{5}{*}{$\begin{array}{c}\text { Diameter of } \\
\text { umbrella } \\
\text { mm. } \\
2^{\star} \\
3 \\
3.5 \\
3^{\star} \cdot 8\end{array}$} & \multicolumn{2}{|c|}{$\begin{array}{c}\text { Numbers of marginal } \\
\text { tentacles }\end{array}$} & \multirow[b]{2}{*}{ Locality } \\
\hline & Large & Small & \\
\hline & 8 & 36 & Valentia \\
\hline & 8 & 40 & $50^{\circ} 30^{\prime}$ N., $6^{\circ} 49^{\prime} \mathrm{W}$. \\
\hline & $\begin{array}{l}8 \\
8\end{array}$ & $\begin{array}{l}26 \\
49\end{array}$ & $" \quad$ " \\
\hline
\end{tabular}

In their original description Neppi and Stiasny said as regards the gonads "Gonaden nur am Magen oder sowohl an demselben als am Manubrium". This expression is not quite clear, but their figure leaves no doubt that the gonads are present on the proximal portions of the radial canals as well as on the stomach.

In view of the above observations the species can now be redescribed as follows.

Umbrella bell shaped, about as high as wide; no apical process; jelly thin, thicker in apical region. Velum broad. Stomach cylindrical, about half height of subumbrellar cavity in length; with very slight peduncle. Four radial canals and ring canal narrow. Mouth with four elongated perradial lips each with single terminal nematocyst cluster. Gonads interradial on stomach wall and perradial for short distance along proximal portions of each radial canal. Up to fifty-seven solid marginal tentacles with swollen basal bulbs; four perradial and four interradial tentacles large and approximately of same size, remaining tentacles small and of different sizes. No ocelli. Diameter of umbrella $2 \cdot 0-3.8 \mathrm{~mm}$. Colour of basal bulbs of larger tentacles yellow or brownish; stomach and gonads flecked with yellow or brown.

I was able to make colour notes of the living medusa; the basal bulbs of the eight large tentacles were brilliant yellow, and yellow pigment was also present in the bulbs of the larger tentacles of the series of small ones. In this respect the medusa differed from typical $P$. areolata, in which the colour is much redder and in which most of the tentacle bulbs are pigmented.

Each.mouth lip is continued outwards to form a solid tentacle with several rows of endoderm cells and a single large terminal nematocyst cluster (Fig. I $d$ ).

The gonads on the proximal portions of the radial canals are situated on the sides of the canals and are not continuous over the lower walls of the canals. Each of these gonads appears to be continuous with its neighbouring portion on the interradial wall of the stomach (Fig. I c).

Since the stomach appears often to be badly torn in preserved specimens it is possible that it may be necessary to rely for identification on the number of marginal tentacles and the fact that only eight of these are large. This note 
is therefore written in the hope that others may re-examine their collections of $P$. areolata, in which the tentacles appear to be usually of more uniform size. It is, for instance, interesting to note that Kramp \& Damas (I925, p. 270) mention a specimen $2.5 \mathrm{~mm}$. in height with forty-one tentacles of which only eight were large, the remainder being small.

The hydroid $P$. areolata Alder has generally been assigned to the medusa now known under that name because of the large number of marginal tentacles in the newly liberated medusa. It seems now that there is an equal likelihood that it may belong to $P$. hartlaubi, if this species can also be shown to occur in North Sea or Norwegian waters.

\section{Podocoryne minima (Trinci)}

I have found in Mr Browne's collection a number of specimens labelled Cytaeis sp. (?), together with manuscript notes. The medusae were referred to by Browne (1898) as Cytaeis sp. (?), but were never described. They were found in Plymouth Sound and Cawsand Bay.

These medusae agree in every respect with the medusa described by Trinci (1903) as Cytaeis minima, and discussed by him later (Trinci, I904), having four perradial marginal tentacles and medusa buds on the stomach. The four perradial mouth lips each terminated in a single nematocyst cluster and were typical of Podocoryne. The only difference is in size, the Plymouth specimens being up to about I mm. in height and Trinci's being $0.27-0.33 \mathrm{~mm}$. In size they thus resemble more closely Kramp's Podocoryne simplex from Japan, which was $0.75 \mathrm{~mm}$. in height (Kramp, I928). It seems possible that all three are the same species.

The medusa has not been seen here since and its hydroid is not known.

\section{Phialopsis diegensis Torrey}

Four specimens undoubtedly belonging to this species were given to me by $\mathrm{Mr} \mathrm{P}$. G. Corbin who found them in a ring trawl catch taken in $49^{\circ} 40^{\prime} \mathrm{N}$., II $^{\circ}$ IO $^{\prime}$ W., I 20 miles south-west by south from Fastnet, on April 20 I939.

Phialopsis diegensis was first described by Torrey (1909) from San Diego. It has been described by one or two authors under the name of Eirene viridula, and these erroneous identifications have been cleared up by Kramp (I936) in his synonymy of that species. The best figures of the species are those given by Bigelow (1909, as Eirene) from a single specimen. Since this medusa has not often been recorded and since its identification may at first give some difficulty, it seems worth while to give some figures of the specimens I have seen and mention a few minor structural details not given in previous descriptions.

The specimens were about IO-I $5 \mathrm{~mm}$. in diameter. Of these, two specimens, Io and I5 mm. ${ }^{\star}$ in diameter, had ten and thirteen large marginal tentacles

* This specimen had two young actinians attached to the stomach. 
respectively. In both the peduncle was very slight and scarcely perceptible at first glance. In the 1o $\mathrm{mm}$. specimen (Fig. $2 a$ ) in which almost the whole of the umbrella margin was intact I counted the following numbers of marginal organs between every two tentacles:

$$
\begin{array}{ll}
\text { Rudimentary marginal bulbs } & 2-6 \\
\text { Marginal cirri } & 3-9 \\
\text { Marginal vesicles } & 2-5 \text {, with I-6 concretions, } \\
& \quad \text { usually } 4
\end{array}
$$

The $15 \mathrm{~mm}$. specimen had fifty-seven rudimentary marginal bulbs. In both these specimens the gonads were only slightly developed.

The other two specimens, each about $\mathrm{I} 4 \mathrm{~mm}$. in diameter, had fully formed peduncles. In one specimen (Fig. $2 b$ ) there were eighteen marginal tentacles,

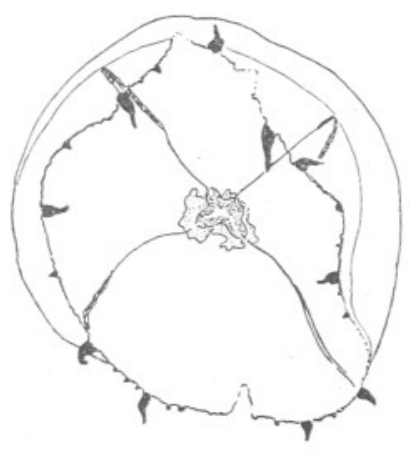

$a$

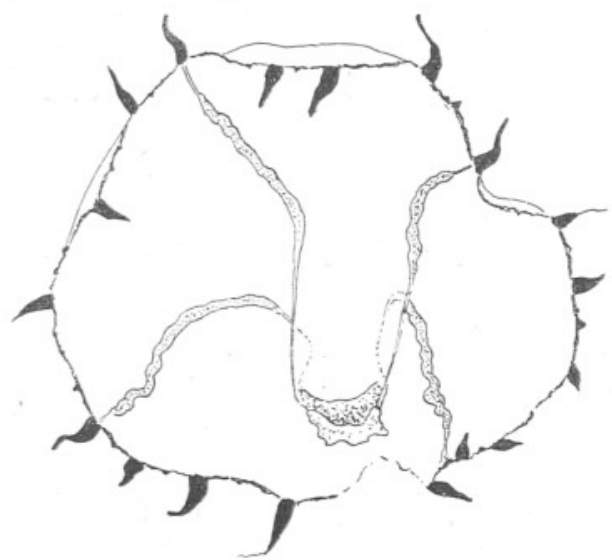

$b$

Fig. 2. Phialopsis diegensis: appearance of preserved specimens; $a$, Io $\mathrm{mm}$. diameter; $b$, $14 \mathrm{~mm}$. diameter.

but the other was too damaged to count. In both, the gonads were well developed. The umbrellas had obviously contracted much more than in the other two specimens, and in life their diameters would have been larger. The distal ends of the gonads were thus thrown into sinuous folds.

The gonads ended a short distance before the ring canal, and, as far as I could see from hand sections, the gonadial tissue was continuous over the lower wall of the radial canal and there was no median furrow.

The base of the remarkably short stomach appears to be characteristic (Fig. $3 a, b$ ). It is attached to the end of the peduncle along the arms of a small perradial cross, and there is a distinct dilatation at each of the four points where a radial canal enters, though not quite so pronounced as in Eirene viridula. Four well marked shoulders are thus formed, which run down to the mouth lips and give the appearance of a raised cross when viewed from above (this appearance is indicated in Bigelow's figure, I909, pl. 36, fig. 3). 


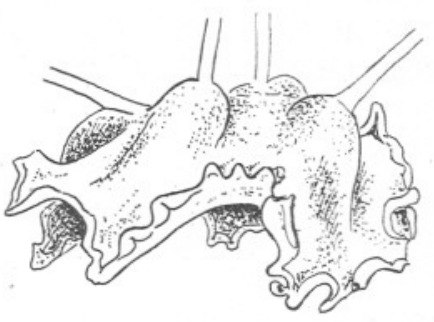

$a$

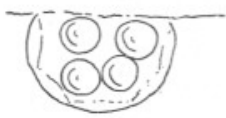

C
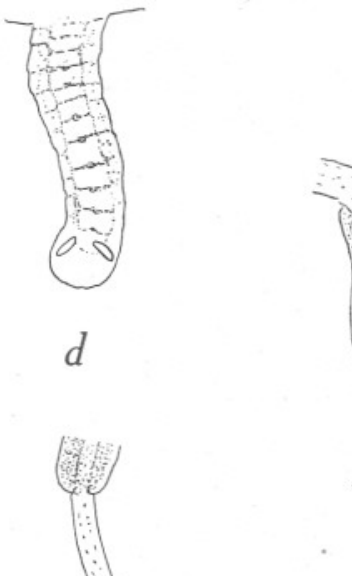

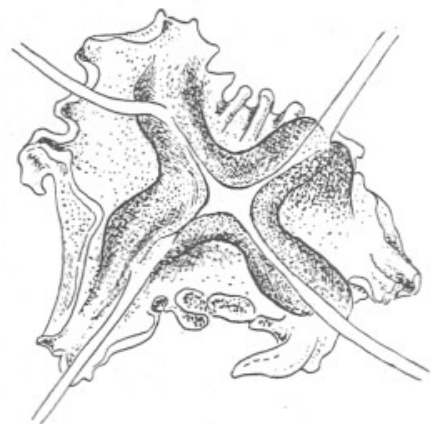

b

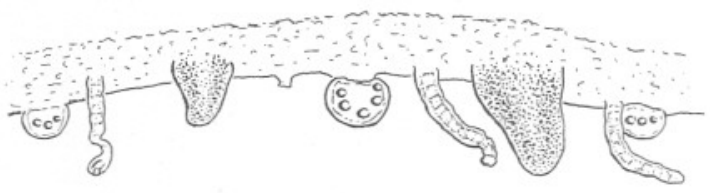

$e$

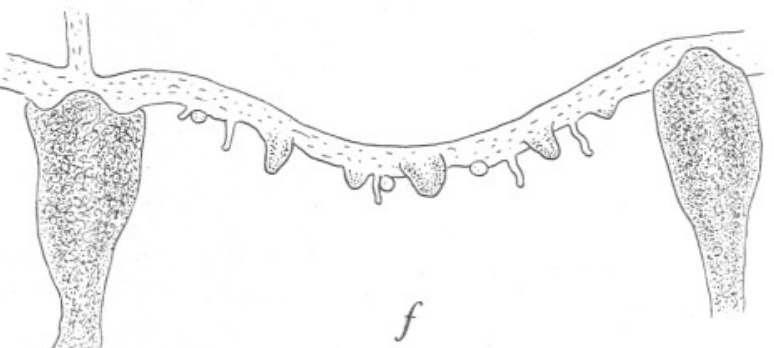

$g$

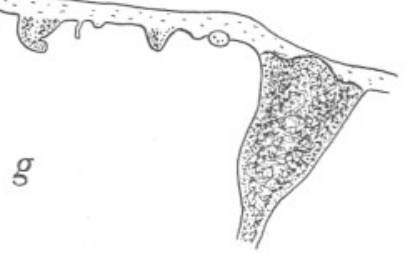

Fig. 3. Phialopsis diegensis: $a, b$, stomach of $10 \mathrm{~mm}$. specimen viewed from side and above; $c$, marginal vesicle; $d$, marginal cirrus; $e$, portion of umbrella margin of $15 \mathrm{~mm}$. specimen, enlarged; $f, g$, umbrella margin between two adjacent tentacles in $\mathrm{I}_{3}$ and $\mathrm{I} 5 \mathrm{~mm}$. specimens. 
The basal bulbs of the marginal tentacles are large and conical, and appear elongated or short and broad according to their degree of contraction. Each bulb has a slight rounded median spur clasping the umbrella margin (Fig. $3 f, g$ ). I could see no excretory pores.

\section{REFERENCES}

Bigelow, Henry B., I909. Reports on the Scientific Results of the Expedition to the Eastern Tropical Pacific... XVI. The Medusae. Mem. Mus. Comp. Zoöl. Harvard, Vol. xxxvII, pp. I-243.

BRowne, EDWARD T., I898. On the pelagic fauna of Plymouth for September, I897. fourn. Mar. Biol. Assoc., Vol. v, pp. I86-92.

Kramp, P. L., I928. Papers from Dr Th. Mortensen's Pacific Expedition I9I4-I6, XLIII. Hydromedusae I. Anthomedusae. Vidensk. Medd. naturh. Foren. Køjb., Bd. 85, pp. 27-64.

- I936. On the Leptomedusae of the genera Eirene Eschscholtz and Helgicirrha Hartlaub. Vidensk. Medd. naturh. Foren. Køjb., Bd. 99, pp. 239-62.

Kramp, P. L. \& Damas, D., I925. Les méduses de la Norvège. Introduction et partie spéciale I. Vidensk. Medd. naturh. Foren. Kojb., Bd. 80, pp. 217-323.

Neppi, Valeria \& Stiasny, Gustav, I9I3. Die Hydromedusen des Golfes von Triest. Arb. Zool. Inst. Univ. Wien u. Zool. Stat. Triest, Bd. xx, pp. 23-9o.

Torrey, Harry Beal, I909. The Leptomedusae of the San Diego region. Univ. Calif. Publ. Zool., Vol. 6, No. 2, pp. II-3I.

TrincI, GiUlio, I903. Di una nuova specie di Cytaeis gemmante del Golfo di Napoli. Mitt. Zool. Stat. Neapel, Bd. I6, Heft I/2, pp. I-34.

- I904. Notizie sulla gemmazione della "Dysmorphosa minuta" A. G. Mayer e sulla biologia delle Margelidae in generale. Monit. Zool. Ital. Firenze, Vol. xv, Anno xv, pp. 304-Io. 